WARSZTATY Z GEOGRAFII TURYZMU

ISBN 978-83-7525-586-7 $\quad$ s. 9-20

http://dx.doi.org/10.18778/7525-586-7.02

Anna GARDZIŃSKA

Dawid MILEWSKI

Adam PAWLICZ

Uniwersytet Szczeciński

Katedra Zarządzania Turystyką

\title{
ROLA SAMORZĄDU LOKALNEGO I BRANŻY TURYSTYCZNEJ W KSZTAŁTOWANIU SYSTEMU INFORMACJI TURYSTYCZNEJ NA PRZYKŁADZIE WOJEWÓDZTWA ZACHODNIOPOMORSKIEGO
}

Informacja turystyczna odgrywa istotną rolę w rozwoju turystyki na szczeblu regionalnym i lokalnym. To właśnie rzetelna, aktualna, kompleksowa informacja przekazana potencjalnemu turyście dotycząca atrakcji turystycznych i lokalnych produktów turystycznych wpływa na wielkość ruchu turystycznego. Podstawą odpowiedniego przepływu informacji na terenie województwa jest prawidłowo funkcjonujący system informacji turystycznej oparty na pracy placówek informacji turystycznej (punktów i centrów informacji turystycznej). Za tworzenie regionalnego systemu informacji turystycznej odpowiedzialny jest samorząd terytorialny, przedsiębiorstwa turystyczne oraz organizacje turystyczne działające na danym terenie. Jednakże często podmioty te zmuszone są do tworzenia systemu we własnym zakresie i do zbierania oraz uzupełniania informacji o walorach i zagospodarowaniu turystycznym.

Celem niniejszego opracowania jest pokazanie, w kontekście wyników przeprowadzonych badań w województwie zachodniopomorskim, że wy- 
kreowanie sprawnie funkcjonującego systemu informacji turystycznej wymaga aktywnej współpracy samorządu lokalnego z branżą turystyczną.

\section{Regionalny system informacji turystycznej}

Informacja turystyczna jest to przekazywanie zainteresowanym turystom wszelkich wiadomości o walorach turystycznych oraz elementach zagospodarowania turystycznego. Informacja turystyczna to nie tylko uporządkowany zbiór danych służących organizatorom i konsumentom usług turystycznych oraz metodologia gromadzenia, przetwarzania, weryfikowania i udostępniania danych, ale także system obejmujący sieć centrów i punktów informacji turystycznej. W systemie tym wspólnie przyjętym normom podlegają podstawowe zakresy informacji, tryb ich poszukiwania, gromadzenia, aktualizacji i udostępniania. System informacji turystycznej wiążą wspólne narzędzia pracy, zwłaszcza komputerowe bazy danych (KODŁUBAŃSKI, GORDON $\mathrm{i}$ inni 2003).

$\mathrm{W}$ tworzeniu systemu informacji turystycznej na szczeblu regionalnym i lokalnym ważną rolę odgrywa samorząd terytorialny. Jednostki samorządu terytorialnego są członkami wielu stowarzyszeń (w tym regionalnych i lokalnych organizacji turystycznych) i związków komunalnych. Stanowią one również najliczniejszą grupę gestorów centrów informacji turystycznej.

Samorządy województw kładą duży nacisk na rozwój systemu informacji turystycznej $\mathrm{w}$ regionie, czego wyrazem są zapisy dotyczące rozwoju regionalnego systemu informacji turystycznej $\mathrm{w}$ strategicznych dla województwa dokumentach, przede wszystkim w strategiach rozwoju turystyki. Tworzą one również w swoich strukturach wydziały (biura) promocji, których zadaniem jest realizowanie różnych zadań z zakresu rozwoju turystyki w regionie, m.in.: promocja regionu jako atrakcyjnego turystycznie, współdziałanie z gminami, organizacjami i stowarzyszeniami turystycznymi na rzecz kreowania i rozwoju regionalnych produktów turystycznych, współpraca z ministerstwem właściwym ds. turystyki, z Polską Organizacją Turystyczną oraz $\mathrm{z}$ regionalną organizacją turystyczna, wspieranie działań na rzecz gromadzenia informacji $\mathrm{w}$ zakresie atrakcji i produktów turystycznych województwa.

Na szczeblu lokalnym za system informacji turystycznej odpowiada zaś samorząd powiatowy i gminny. Zarówno Ustawa z dnia 5 czerwca 1998 r. o samorządzie powiatowym, jak i Ustawa z dnia 5 marca 1990 r. o samorzadzie gminy 
ujmuje, że jednostki te mają za zadanie zaspokojenie zbiorowych potrzeb, do których należą m.in. potrzeby w zakresie kultury, kultury fizycznej i turystyki oraz potrzeby informacyjne. Powiatowe centra informacji turystycznej powiązane są organizacyjnie z samorządami powiatowymi lub lokalnymi organizacjami turystycznymi. W urzędach powiatowych zadania dotyczące turystyki i informacji turystycznej przypisane są poszczególnym wydziałom, których zadania w zakresie informacji turystycznej opierają się na: zbieraniu informacji o działających na obszarze powiatu instytucjach turystycznych oraz organizowanych przez nie imprezach turystycznych, gromadzeniu informacji o powiecie oraz współpracy z jednostkami organizacyjnymi w zakresie gromadzenia i wykorzystania informacji.

Gminne ośrodki informacji turystycznej powiązane są z lokalnymi organizacjami turystycznymi lub samorządami gminnymi. Działają one jako jednostki lub zakłady budżetowe, samodzielne lub w strukturze innych organizacji. Do zadań samorządu gminnego powinno należeć przede wszystkim zbieranie danych o walorach turystycznych i zagospodarowaniu turystycznym na terenie gminy oraz ich aktualizacja i uzupełnianie. Każda gmina posiada bowiem przynajmniej cząstkowe informacje dotyczące walorów i zagospodarowania turystycznego. Dysponowanie takimi informacjami jest wynikiem prac terenowych bądź osobistego kontaktu z właścicielami lub administratorami obiektów turystycznych.

Istotną rolę $\mathrm{w}$ kształtowaniu systemu informacji turystycznej (it) $\mathrm{w}$ regionie odgrywają organizacje turystyczne - regionalne (ROT) i lokalne (LOT), które uczestniczą w tworzeniu internetowych baz danych systemu it. Organizacje te nie zawsze dysponują własnymi centrami it, ich zadaniem jest jednak organizowanie współpracy istniejących placówek, w tym wymiany informacji i doświadczeń oraz organizacja szkoleń. Regionalne i lokalne organizacje turystyczne są często zaangażowane $\mathrm{w}$ organizację imprez targowych, prezentacji turystycznych, konkursów i wystaw, które odgrywają również istotną rolę $\mathrm{w}$ zakresie promocji i informacji turystycznej. Ważny wydaje się również fakt, iż wiodącą pozycję w działaniach ROT i LOT zajmuje promocja poprzez wydawnictwa turystyczne i strony internetowe.

Działalność informacyjną i promocyjną $\mathrm{w}$ regionie realizują również inne organizacje turystyczne, tj. organizacje branżowe (np. regionalne oddziały Polskiej Izby Turystyki), stowarzyszenia turystyczne o zasięgu regionalnym i lokalnym, społeczne organizacje turystyczne (np. regionalne oddziały PTTK czy też PTSM) oraz organizacje młodzieżowe i zawodowe (np. ludowe kluby turystyczne, Związek Młodzieży Wiejskiej, Związek Gmin Jurajskich).

Podmiotami odpowiedzialnymi za tworzenie systemu informacji turystycznej są również przedsiębiorstwa turystyczne. Wkład przedsiębiorstw 
turystycznych we współtworzenie systemu informacji opiera się przede wszystkim na bezpośrednim udzielaniu informacji turystom, a także na przekazywaniu administratorowi internetowego systemu informacji turystycznej zmian, nowości oraz aktualności dotyczących funkcjonowania danego przedsiębiorstwa na rynku turystycznym.

$\mathrm{Na}$ tworzenie systemu informacji turystycznej mają wpływ przede wszystkim przedsiębiorstwa hotelarskie oraz biura podróży jako podmioty rynku turystycznego. Organizatorzy turystyczni oraz pośrednicy turystyczni proponują klientom imprezy turystyczne bądź usługi turystyczne. Klienci biur podróży oczekują zatem jak najpełniejszej informacji o świadczonych usługach turystycznych, walorach turystycznych, istotnych przepisach prawa obowiązujących w kraju (regionie, miejscowości) docelowym. Informacja świadczona jest klientom przede wszystkim w formie ustnej (bezpośrednie udzielenie informacji klientowi), a także w postaci materiałów informacyjnych w wersji drukowanej (foldery, broszury, mapy, przewodniki, ulotki) i elektronicznej. Usługę informacyjną $w$ hotelu bądź innym obiekcie zbiorowego zakwaterowania świadczy głównie recepcja, a w dużych hotelach także hotelowe biuro obsługi (MERSKI, PIOTROWSKI 2008). Informacji turystycznej udziela się gościom hotelowym, jak i przygodnym pytającym niekorzystającym z usług hotelu.

\section{Założenia i metodyka badań}

Badania dotyczące współpracy samorządu lokalnego z branżą turystyczną $\mathrm{w}$ zakresie kształtowania systemu informacji turystycznej w województwie zachodniopomorskim przeprowadzono $\mathrm{w}$ latach 2008-2010 $\mathrm{w}$ ramach projektu „Współpraca samorządu lokalnego i branży turystycznej w tworzeniu systemu informacji turystycznej $\mathrm{w}$ dobie społeczeństwa informacyjnego" realizowanego przez Katedrę Zarządzania Turystyką oraz Katedrę Finansów Publicznych Wydziału Zarządzania i Ekonomiki Usług Uniwersytetu Szczecińskiego ${ }^{1}$.

Badaniami objęto 30 spośród 114 gmin województwa zachodniopomorskiego oraz 119 przedsiębiorców turystycznych. Selekcji gmin dokonano na podstawie iloczynu dwóch wskaźników: taksonomicznego miernika rozwo-

${ }^{1}$ Wspótpraca samorzadu lokalnego i branży turystycznej w tworzeniu systemu informacji turystycznej $w$ dobie społeczeństwa informacyjnego, Projekt badawczy Ministerstwa Nauki i Szkolnictwa Wyższego, N N114 1078 33, 2007-2010; kierownik projektu: dr hab. prof. US Aleksander Panasiuk. 
ju atrakcyjności turystycznej oraz miernika współpracy samorządu lokalnego i przedsiębiorców turystycznych w zakresie informacji turystycznej.

Narzędziem badawczym wykorzystanym w badaniach był kwestionariusz ankietowy. Przedmiotem badań były jednostki samorządu terytorialnego odpowiedzialne za utrzymanie informacji turystycznej w regionie, punkty informacji turystycznej oraz przedsiębiorstwa turystyczne.

\section{Ocena współpracy samorządu lokalnego i branży turystycznej w kształtowaniu systemu informacji turystycznej w województwie zachodniopomorskim w świetle przeprowadzonych badań}

Spośród 30 przebadanych gmin placówka informacji turystycznej znajdowała się w 27. Jedynie w gminach Białogard, Kamień Pomorski i Dębno nie działała informacja turystyczna. Placówka it w badanych gminach miała najczęściej charakter centrum informacji turystycznej bądź punktu informacji turystycznej. Placówka it w zdecydowanej większości przypadków jest czynna przez cały rok (w 22 gminach).

Wszystkie punkty informacji turystycznej są wyposażone w komputer z przyłączem internetowym. W przypadku 24 punktów komputer posiadał stałe łącze internetowe. W 24 gminach placówki wyposażone były we własną skrzynkę elektroniczna, a w 14 placówki it miały własną stronę internetową. Wszystkie punkty wyposażone były $\mathrm{w}$ dostępną dla turysty biblioteczkę z wydawnictwami dotyczącymi produktu turystycznego regionu. Średnia liczba etatów w badanych placówkach wahała się między 1,96 poza sezonem a 2,19 w trakcie sezonu turystycznego. Ich pracownicy bardzo często mają wykształcenie kierunkowe. Jedynie w 13 spośród 32 przebadanych placówek personel nie miał wykształcenia związanego z turystyka, a tylko $\mathrm{w}$ trzech brak było pracownika posługującego się językiem angielskim.

W zakresie oceny funkcjonowania placówek it oceniano: oznakowanie placówki, jej lokalizację, godziny otwarcia oraz jakość materiałów informacyjnych. We wszystkich przypadkach przedstawiciele samorządu zdecydowanie wyżej oceniali poszczególne aspekty funkcjonowania placówek informacji turystycznej.

W opinii przedstawicieli samorządu terytorialnego, niemal wszystkie elementy funkcjonowania placówek it działają dobrze lub bardzo dobrze. 
Przedsiębiorcy, pomimo że generalnie również oceniają pozytywnie funkcjonowanie placówek we wszystkich aspektach, mają zastrzeżenia do godzin otwarcia (jedynie $56 \%$ ocenia je dobrze lub bardzo dobrze) oraz do oznakowania placówek.

Zakres działalności placówek it obejmował następujące usługi:

- świadczenie informacji turystycznej o charakterze lokalnym (26 z 27 gmin),

- świadczenie informacji o regionie (22),

- współpracę z gestorami bazy noclegowej (26),

- współpracę z branżą gastronomiczną (20),

- współpracę z branżą transportową (18),

- współpracę z biurami podróży (15),

- współpracę z podmiotami świadczącymi inne usługi turystyczne (np. z przewodnikami, pilotami wycieczek) (20),

- sprzedaż pamiątek (14),

- gromadzenie informacji na potrzeby lokalne (20),

- poradnictwo dla turystów indywidualnych (25),

- poradnictwo dla organizatorów wypoczynku zbiorowego (22),

- wydawanie i kolportaż materiałów promocyjnych i informacyjnych (25).

Placówki informacji turystycznej są $\mathrm{w}$ znacznej mierze finansowane ze środków publicznych. W 18 gminach (z 26) ankietowani wskazywali na 100-procentowe finansowanie placówki ze środków publicznych. W pozostałych (poza jednym punktem zarządzanym przez organizację pozarządową) udział finansowania był znacznie większy niż 50\%. Pozostała część kosztów funkcjonowania placówek informacji turystycznej pochodziła głównie ze środków własnych wypracowanych przez placówki oraz funduszy celowych. Jedynie $\mathrm{w}$ dwóch gminach finansowanie placówek informacji turystycznej bazowało w niewielkim stopniu na składkach przedsiębiorców.

Głównym nośnikiem komunikacji pomiędzy organizacjami odpowiedzialnymi za marketing terytorialny a potencjalnymi turystami jest Internet. Przeprowadzone badania wykazały, że wszystkie 114 gmin województwa zachodniopomorskiego posiada własne strony internetowe. Informacje przydatne dla potencjalnych turystów posiada jedynie część gmin województwa. Zdecydowana większość stron internetowych gmin zawiera informacje na temat atrakcji turystycznych znajdujących się na terenie gminy oraz znajdujących się na jej terenie obiektów noclegowych. Wśród wyselekcjonowanych 30 gmin objętych szczegółowym badaniem, wszystkie wykorzystują Internet w komunikacji z potencjalnymi turystami. Większość gmin (19) nie miała odrębnego adresu internetowego, tj. innego adresu www niż strona główna gminy, przeznaczonego dla potencjalnych turystów, a jedynie tzw. zakładkę 
umożliwiającą turyście znalezienie odpowiednich informacji po wejściu na stronę główną gminy. W przypadku siedmiu gmin, obok osobnej strony internetowej poświęconej turystyce funkcjonuje równolegle zakładka na stronie głównej gminy. Stosunkowo rzadko korzystano z umieszczania informacji związanych z turystyką na innych stronach www. Administracją stron prawie wyłącznie zajmują się pracownicy badanych jednostek. Na pytanie o częstość aktualizacji informacji na stronach internetowych przeważała odpowiedź: „w miarę potrzeb” (17) oraz „kilka razy w miesiącu” (7).

Badania przeprowadzone wśród przedsiębiorców turystycznych wykazały, iż zdecydowana większość wykorzystuje Internet w promocji swoich produktów. Spośród 119 przebadanych przedsiębiorców 95 zadeklarowało wykorzystanie w swojej działalności gospodarczej tego nośnika informacji. Najpopularniejsze formy wykorzystania Internetu przez badanych przedsiębiorców to budowa własnej strony internetowej, korzystanie ze stron innych przedsiębiorstw (pośredników turystycznych) oraz e-mailing.

Poziom współpracy w zakresie tworzenia i utrzymywania informacji turystycznej $\mathrm{w}$ badanych 30 gminach zmierzony został zarówno wśród przedstawicieli samorządu terytorialnego, jak i przedsiębiorstw turystycznych. Poziom zaangażowania samorządu $\mathrm{w}$ tworzenie i utrzymanie informacji turystycznej w opinii samorządu był stosunkowo wysoki, podczas gdy zaangażowanie przedsiębiorców zostało ocenione znacznie niżej (rys. 1). Zaangażowanie organizacji turystycznych $\mathrm{w}$ budowę systemu informacji turystycznej w gminach ankietowani przedstawiciele samorządu ocenili na tym samym poziomie co w przypadku przedsiębiorstw turystycznych.

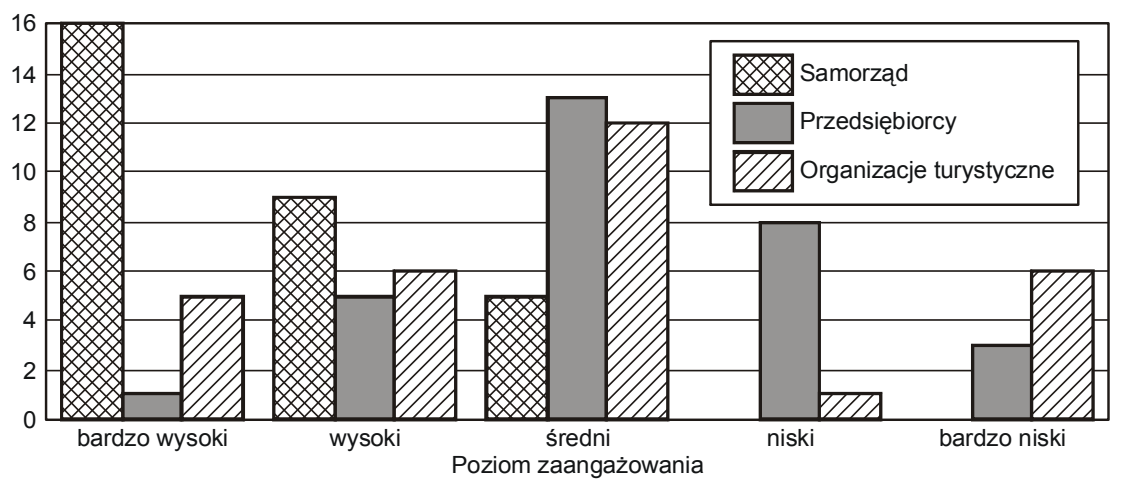

Rys. 1. Zaangażowanie przedsiębiorców, samorządu terytorialnego oraz organizacji turystycznych w tworzenie informacji turystycznej w gminach Źródło: opracowanie własne 
Niezbyt intensywne zaangażowanie przedsiębiorców w funkcjonowanie systemu informacji turystycznej potwierdziły badania przedsiębiorców. Spośród 119 ankietowanych przedsiębiorstw jedynie 68 (57\%) przyznało, iż przekazują informacje o swojej ofercie dla potencjalnych turystów do samorządu gminnego. Współpraca z samorządem powiatowym, organizacjami turystycznymi oraz innymi przedsiębiorstwami była na jeszcze niższym poziomie (rys. 2). Należy podkreślić, iż współpraca z gminami była zdecydowanie częściej (w 71\%) wskazywana przez przedsiębiorstwa małe niż przez mikroprzedsiębiorstwa (48\%). Podobna sytuacja miała miejsce w przypadku współpracy z pozostałymi podmiotami. Nieco częściej na współpracę z gminami wskazywali również reprezentanci sektora usług noclegowych (64\%), niż gastronomicznych (51\%) i biur podróży (31\%). Podobnie sytuacja wyglądała $\mathrm{w}$ przypadku współpracy z powiatem i organizacjami turystycznymi. Współpraca $z$ innymi przedsiębiorstwami, zgodnie z oczekiwaniami, była domeną biur podróży (62\%) oraz hotelarzy (55\%). Najrzadziej z innymi przedsiębiorstwami współpracują przedsiębiorstwa gastronomiczne.

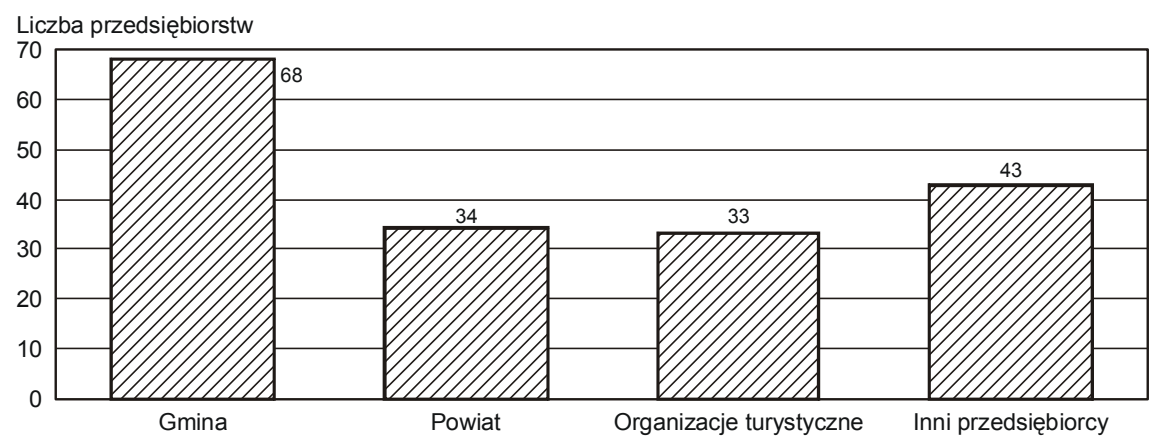

Rys. 2. Liczba przedsiębiorstw współpracujących z poszczególnymi podmiotami w zakresie przekazywania informacji o swoim produkcie $(\mathrm{n}=119)$

Źródło: opracowanie własne

Poza współpracą z przedstawicielami branży turystycznej dla samorządu gminnego bardzo istotna jest wymiana wiedzy oraz doświadczeń $z$ innymi podmiotami samorządu terytorialnego w badanym obszarze. Zdecydowana większość ankietowanych przedstawicieli samorządu gminnego przyznała się do współpracy z samorządem województwa, powiatem, innymi gminami, ze stowarzyszeniami turystycznymi, ZROT-em i innymi podmiotami z zagranicy (rys. 3). 


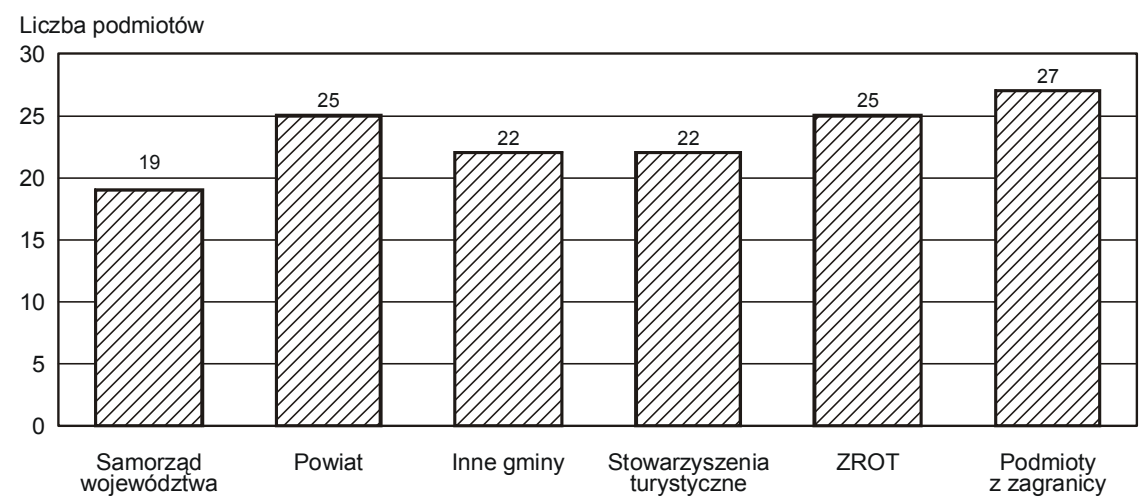

Rys. 3. Podmioty, z którymi współpracują badani przedstawiciele samorządu gminnego w zakresie informacji turystycznej $(\mathrm{n}=30)$ Źródło: opracowanie własne

Współpraca pomiędzy podmiotami publicznymi (ZROT i stowarzyszenia turystyczne są finansowane w przeważającej części ze środków publicznych) jest zatem zdecydowanie bardziej intensywna od współpracy samorządu z branżą turystyczną. Niski poziom współpracy samorządu gminnego z branżą nie dotyczy jedynie informacji turystycznej. Najczęstszą formą współpracy jest umieszczenie informacji o ofercie przedsiębiorstwa na stronie internetowej gminy oraz, ewentualnie, wydawanie wspólnych folderów na temat regionu. Co czwarte przedsiębiorstwo bierze udział wspólnie z samorządem $\mathrm{w}$ targach turystycznych. Współpraca z powiatami, organizacjami branżowymi oraz innymi przedsiębiorstwami jest udziałem jedynie kilku procent badanych przedsiębiorców (rys. 4).

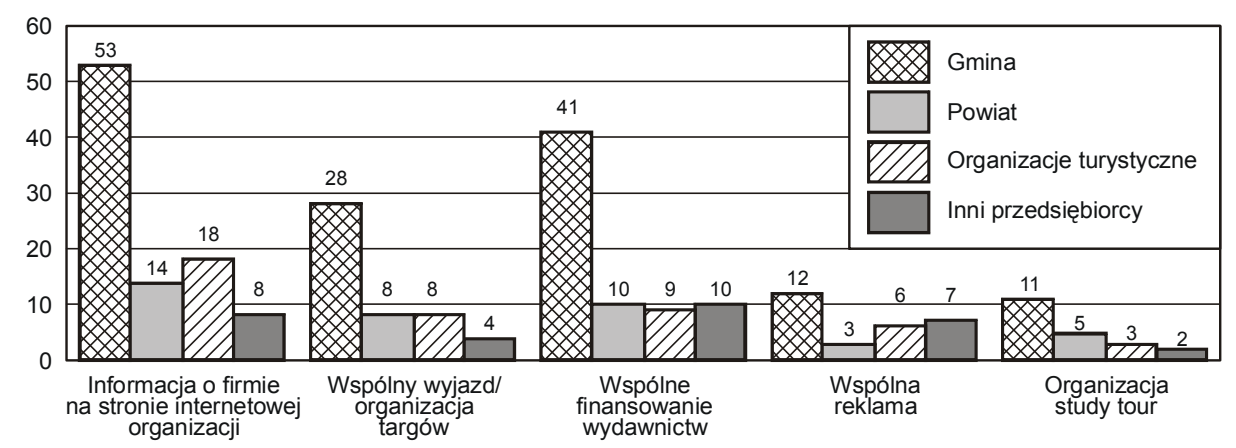

Rys. 4. Współpraca przedsiębiorców turystycznych z wybranymi jednostkami samorządu, organizacjami turystycznymi oraz innymi przedsiębiorstwami w wybranych dziedzinach Źródło: opracowanie własne 
Współpraca publiczno-prywatna w zakresie informacji turystycznej może przynieść wymierne korzyści zarówno przedsiębiorcom, jak i samorządowi. Wydaje się, że poziom tej współpracy w badanych gminach znajduje się na niskim poziomie, niemniej jednak jest on z pewnością wyższy od poziomu współpracy w pozostałych gminach województwa. Intensyfikacja współpracy możliwa jest jednak jedynie w przypadku poprawy świadomości konieczności tego rodzaju działań wśród przedsiębiorców i stworzenia odpowiednich bodźców ze strony samorządu gminnego.

Budowa potencjalnego Internetowego Systemu Informacji Turystycznej (ISIT) dla całego województwa mogłaby w znaczący sposób usprawnić przekaz informacji pomiędzy samorządem gminnym a turystami, znajdującymi się $\mathrm{w}$ fazie podejmowania decyzji o wyjeździe. Sukces powstania tego rodzaju platformy, podobnie jak w przypadku innych przedsięwzięć o charakterze sieciowym, zależy od liczby i poziomu zaangażowania uczestniczących w nim podmiotów, marketingu przekładającego się na konkretne korzyści dla uczestników oraz jakości przekazywanych informacji.

Na pytanie o chęć współpracy i uczestnictwa w systemie, zdecydowana większość badanych przedstawicieli samorządu (ponad 90\%) odpowiedziała twierdząco. Przedsiębiorcy, również w większości, deklarowali chęć współpracy i uczestnictwa $\mathrm{w}$ tego rodzaju programie, niemniej jednak $\mathrm{w}$ znacznie mniejszym stopniu (odpowiednio 60 i 65\% odpowiedzi twierdzących).

O ile chęć uczestnictwa deklarowała zdecydowana większość badanych pod tym kątem samorządowców i przedsiębiorców, na pytanie o ewentualne finansowanie ISIT, obie grupy odpowiadały raczej przecząco (rys. 5).

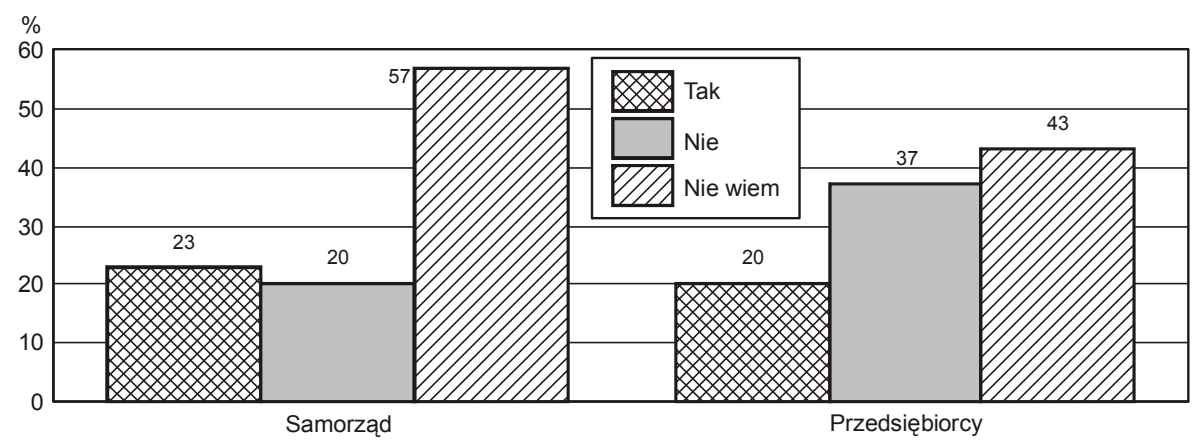

Rys. 5. Deklarowana chęć finansowania Internetowego Systemu Informacji Turystycznej (ISIT) wśród badanych przedstawicieli samorządu gminnego oraz przedsiębiorców turystycznych (odpowiednio $\mathrm{n}=30$ i $\mathrm{n}=119$ ) Źródło: opracowanie własne 
Obie grupy respondentów zostały również zapytane o podmiot, który powinien finansować powstanie ISIT. Zarówno przedstawiciele samorządu, jak i przedsiębiorcy wskazali na gminy jako główny podmiot finansujący tego rodzaju przedsięwzięcie oraz na przedsiębiorców jako podmiot, który powinien uczestniczyć $\mathrm{w}$ finansowaniu ISIT w stopniu najmniejszym (rys. 6). Faktem jest, że udział samorządu w finansowaniu ISIT w opinii przedstawicieli samorządu powinien być mniejszy, podobnie jak udział przedsiębiorstw turystycznych, to jednak nie występuje zjawisko tzw. przerzucania się odpowiedzialnością, co należy ocenić niewątpliwie pozytywnie.

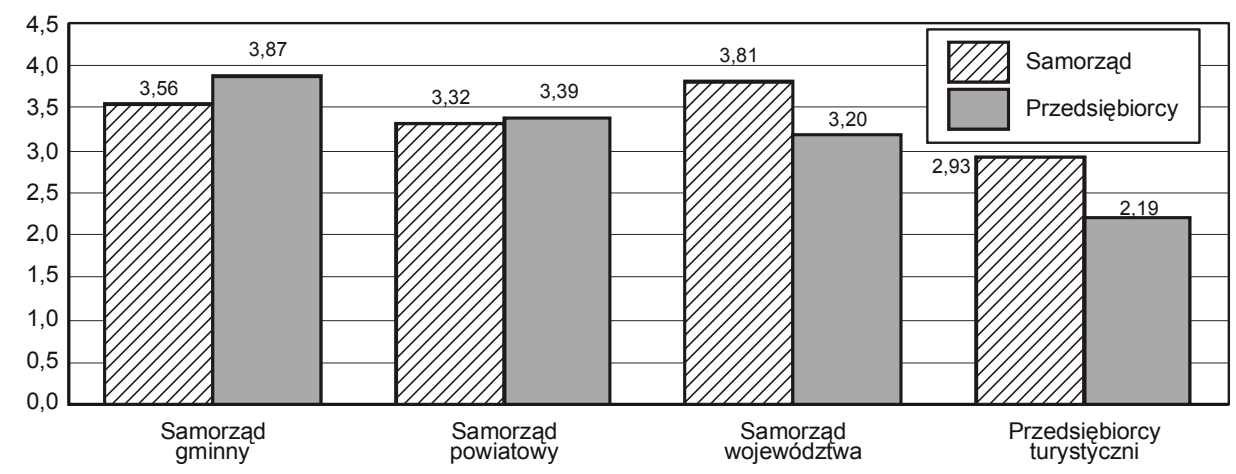

Rys. 6. Proponowany udział w finansowaniu ISIT przez poszczególne podmioty w opinii przedstawicieli samorządu oraz przedsiębiorców turystycznych $(n=30$ i n = 119); 0 oznacza brak finansowania, a 5 największy udział w finansowaniu Źródło: opracowanie własne

Należy podkreślić, że zarówno samorząd, jak i przedsiębiorcy oczekują znacznego wsparcia finansowania systemu przez samorząd powiatowy oraz wojewódzki.

\section{Podsumowanie}

W przeprowadzonych badaniach poziom współpracy pomiędzy podmiotami samorządu terytorialnego a przedsiębiorstwami turystycznymi został zmierzony przy użyciu kilku wskaźników, takich jak zawartość stron internetowych gmin i badanych przedsiębiorców z branży turystycznej, deklarowana chęć współpracy w zakresie wymiany informacji, wyjazdu na targi, 
wspólne finansowanie wydawnictw i innych przedsięwzięć marketingowych itp. Ze względu jednak na brak podobnych badań w innych regionach kraju (tj. brak punktu odniesienia) trudno jest jednoznacznie określić, czy poziom współpracy w badanych gminach jest wysoki czy niski. Na podstawie przedstawionych wyników można jednak sformułować kilka wniosków w zakresie współpracy publiczno-prywatnej podejmowanej w ramach tworzenia informacji turystycznej:

- przedsiębiorstwa turystyczne najchętniej współpracują z samorządem gminnym;

- im większe przedsiębiorstwo, tym skłonność do współpracy większa;

- przedsiębiorstwa stosunkowo niechętnie angażują się finansowo w projekty związane z informacją turystyczną, czego oczekują samorządowcy;

- zarówno przedsiębiorcy, jak i samorządowcy zgadzają się, iż główny ciężar utrzymania informacji turystycznej w regionie powinien ponosić samorząd terytorialny, co oznacza utrzymanie status quo;

- zarówno przedsiębiorcy, jak i samorządowcy stosunkowo wysoko oceniają działalność istniejących punktów informacji turystycznej.

Przeprowadzone badania w województwie zachodniopomorskim mogą zatem stanowić punkt wyjścia do tworzenia koncepcji modelowej współpracy JST i branży turystycznej w zakresie tworzenia systemu informacji turystycznej w regionie.

\section{BIBLIOGRAFIA}

KodŁubański W., Gordon A., Kunce R., Piotrowski J.P., Szmytke R., Tekieli B., Walasek J., 2003, Polski system informacji turystycznej, Polska Organizacja Turystyczna, Warszawa.

MERSKI J., PIOTROWSKI J.P., 2008, System informacji a ruch turystyczny, Wyd. „Almamer”, Wyższa Szkoła Ekonomiczna w Warszawie, Warszawa.

Ustawa z dnia 8 marca 1990 r. o samorządzie gminy, Dz.U. 1990, nr 16, poz. 95.

Ustawa z dnia 5 czerwca 1998 r. o samorzadzie powiatowym, Dz.U. 1998, nr 91, poz. 578. 